\title{
What are the Determinants of Misconception About HIV Transmission Among Ever-Married Women in Ethiopia?
}

This article was published in the following Dove Press journal: HIVIAIDS - Research and Palliative Care

\author{
Abdu Seid (D)' \\ Mohammed Ahmed (iD ${ }^{2}$ \\ 'Department of Midwifery, Woldia \\ University, Woldia, Ethiopia; \\ ${ }^{2}$ Department of Public Health, Woldia \\ University, Woldia, Ethiopia
}

Background: Misconceptions are a major barrier to managing and stopping the spread of AIDS, and they cause a negative attitude towards people stricken by this serious disease that might result in grave harm to their physical and emotional spirit. This study aimed to identify determinants about misconceptions of HIV transmission among Ethiopian married women.

Methods: A cross-sectional study was conducted using the 2016 Ethiopian Demographic and Health Survey (EDHS) data set. The samples were selected using a two-stage stratified cluster sampling technique. The data were analyzed with SPSS version 24. Multivariate logistic regression analysis was performed to identify independent predictors of misconception about HIV transmission. An adjusted odds ratio with a 95\% confidence interval and $P$-value $<0.05$ were considered to declare a statistically significant association.

Results: Of the samples of 8893 reproductive-age women, $34 \%, 18.5 \%$, and $14.5 \%$ of women believed that mosquito bites, food sharing with an individual who is HIV seropositive, and witchcraft or supernatural means, respectively, were responsible for the acquisition of HIV/AIDS. Women residing in rural areas ( $\mathrm{AOR}=1.52 ; 95 \% \mathrm{CI}=1.13-2.0)$, did not attend education $(\mathrm{AOR}=2.36 ; 95 \% \mathrm{CI}=1.3-4.23)$, attended primary education $(\mathrm{AOR}=1.8 ; 95 \%$ $\mathrm{CI}=1.03-3.21)$, unemployed $(\mathrm{AOR}=1.17 ; 95 \% \mathrm{CI}=1.04-1.37)$, and had no media access $(\mathrm{AOR}=1.34 ; 95 \% \mathrm{CI}=1.14-1.58)$ were positively associated with the misconception that mosquito bites can transmit HIV.

Conclusion: Misconceptions are highly prevalent and increase the likelihood of the HIV epidemic in Ethiopia. This research revealed that women residing in a rural area, who did not have education, did not have access to media, who were catholic and Muslim religion followers, had not ever been tested for HIV, and unemployed women were strongly associated with a misconception about HIV transmission. Therefore, interventional health education programs should be taken into account to eradicate misconceptions about HIV.

Keywords: misconception, HIV transmission, women, Ethiopia

\section{Introduction}

HIV/AIDS is different from most other diseases as it attacks people in the most productive age groups and is $100 \%$ incurable. Currently, the effect of AIDS is a frontline factor for the sluggish development and performance of the developing countries. ${ }^{1}$ Likewise, HIV/AIDS has been recognized as a pervasive public health issue in Ethiopia since the mid-1980s and it mainly jeopardizes the working population within the creative and reproductive age groups. ${ }^{2,3}$ The national HIV prevalence in Ethiopia among women aged 15-49 years was 1.4\%, 1.5\%, and 0.9\% in 2005,2011 , and 2016 , respectively. ${ }^{4}$
Correspondence: Abdu Seid Email abdus3536@gmail.com 
Evidence shows that the most common ways of transmission of HIV/AIDS are unprotected sexual contact, venous injections with contaminated needles, during blood transfusions, and vertical transmission from mother to child. ${ }^{5}$ But, HIV/AIDS continues to be subject to several misconceptions and misinformed opinions and it's authoritative to grasp how correct and incorrect information could add to individual behavioral shapes. ${ }^{6}$ Regardless of the most important efforts at behavioral modification of HIV transmission, misconceptions and myths remain a vital influence on risky sexual behaviors. ${ }^{7}$

A study done in China showed that 41.8\%, 26.5\%, 24.6\%, $24 \%$, and $70.4 \%$ of women believed that swimming, food sharing, handshaking, talking with an HIV infected person, and mosquito bites, respectively, were responsible for the transmission of HIV/AIDS. ${ }^{8}$ Likewise, another study done in Botswana showed that $39 \%$ of female respondents believe that a person can get infected with HIV/AIDS through mosquito bites. ${ }^{6}$ Also, a study done in Punjab reported that $79.3 \%$ and $85.3 \%$ of ever-married women responded that HIV/AIDS can be transmitted by supernatural means and by food sharing with an HIV/AIDS positive person, respectively. ${ }^{9}$ Similarly, according to the 2016 EDHS report, $70 \%$ of women believed that HIV can be transmitted by mosquito bites and that a person can become infected by sharing food with a person who has HIV.

The different scholars mentioned that married women were more likely exposed to misconceptions about HIV transmission compared to never-married women. ${ }^{7}$ Likewise, women are also at increased risk of HIV because they face a host of structural barriers and contextual gender inequalities such as poverty, economic disempowerment, cultural inequities, increased risk of sexual violence, the gender power imbalance in sexual interactions, and traditional beliefs about its transmission. ${ }^{10,11}$

The misconceptions may be a major barrier to manage and stop the spread of AIDS and it causes a negative attitude towards people stricken by this serious disease that might result in grave harm to their physical and emotional spirit. ${ }^{12,13}$ A study showed that misconceptions about the transmission of HIV/AIDS among HIV seropositive people leads to engaging in risky behaviors and keeps them from taking appropriate action against HIV acquisition and transmission. ${ }^{14}$

According to different studies, various factors are associated with a misconception about HIV transmission; including health illiteracy, ${ }^{15}$ residing in rural areas, ${ }^{5,16}$ lack of education, ${ }^{5,16}$ wealth index, ${ }^{7}$ and religion. ${ }^{7}$
Even if, the provision of accurate information about HIV transmission thrives and continues to increase in most parts of sub-Saharan Africa, incorrect knowledge, in the form of myths and misconceptions about AIDS, also exists, undermining efforts towards reducing HIV transmission. A previous study has mainly examined the effects of myths and misconception on HIV preventive behaviors. ${ }^{17}$ In response to the HIV epidemic, the Ethiopian government developed a 5-year national HIV and AIDS strategic plan (2015-2020), which stated that misconceptions related to HIV need to be avoided to avert transmission trajectory. ${ }^{18}$ However, there was no study done in Ethiopia which explained the determinants of the misconception of HIV transmission. Using the most recent version of the Demographic and Health Survey, this study fills this research gap by identifying determinants that influence misconceptions surrounding HIV transmission among Ethiopian married women.

\section{Methods \\ Data Source}

This study conducted in Ethiopia uses secondary data from the 2016 Ethiopian Demographic and Health Survey (EDHS). The 2016 EDHS sample is stratified and was selected in two stages. Each region was stratified into urban and rural areas, which yielded 21 sampling strata. Samples of enumeration areas (EAs) were selected independently in each stratum in two stages.

In the first stage, 645 EAs were selected with probability proportional to the EA size and with independent selection in each sampling stratum with the sample allocation. The EA size is the number of residential households in the EA as determined in the 2007 PHC. A household listing operation was implemented in the selected EAs, and the resulting lists of households served as the sampling frame for the selection of households in the second stage. In the second stage of selection, a fixed number of 28 households per cluster were selected with an equal probability systematic selection from the newly created household listing. All women aged 15-49 who are usually members of the selected households or who spent the night before the survey in the selected households were eligible for the female survey. ${ }^{4}$

\section{Sample Selection}

To investigate the information on misconceptions about HIV transmission, missing values were omitted from the study since these values might lead to under- or overestimation of the result. Finally, the analytic samples 
were weighted for 8993 ever-married women aged 15-49 years both in urban and rural areas.

\section{Study Variables}

The main outcome variable of this study was a misconception about HIV/AIDS transmission which is measured through three misconceptions related variables that were identified from the EDHS 2016 data. ${ }^{4}$ The variables were: I) HIV can be transmitted through a mosquito bite; II) HIV can be transmitted through sharing food with someone who has HIV/AIDS; and III) HIV can be transmitted through witchcraft or supernatural means. Then, each indicator was dichotomized as $0=$ no and $1=y e s$. The independent variables that were selected from a literature review on factors related to a misconception about HIV transmission include age in years, religion, mother's education, occupation, exposure to media, educational status of the husband, type of place of residence, wealth status, and ever tested for HIV (Yes/No).

\section{Data Processing and Analysis}

For statistical analyses, each misconception was made a binary response. Bivariate analysis (chi-square test) was used to determine the association between misconceptions and socio-demographic factors. Binary logistic regression models were fitted for the three sorts of misconceptions indicators distinctly to determine the determinants of misconceptions among ever-married women. Finally, all necessary statistical procedures incorporated in complex sampling design analysis was applied. Frequencies and weighted percentages of the variables were utilized to explain the profile of the study participants. Multivariate logistic multivariate analysis was conducted to independent predictors by adjusting the covariates. Sample weighting was applied for adjustments of cluster sampling design and sampling probabilities through strata and clusters. The info was analyzed using SPSS version 24. Adjusted odds ratios (AOR) and $P$-value.

\section{Ethics Approval and Consent to Participate}

Ethical clearance for the study is not required since it is secondary data analysis from the EDHS 2016 database. The researchers received the survey data from the USAIDDHS program and then the researchers of this study maintained the confidentiality of the data. Consent was obtained from the study participants before study commencement.

\section{Results}

\section{Participant Characteristics}

A total of 8893 samples of reproductive age women within the EDHS 2016 were included and analyzed. The majority of respondents $(82.6 \%)$ were rural residents and $43.9 \%$ were in aged between $25-34$ years; $59.2 \%$ of the respondent did not have any education. The majority of respondents $(60.1 \%)$ had no access to media. Furthermore, $14.5 \%, 18.5 \%$, and $34 \%$ of the participants said that HIV/AIDS could be transmitted through witchcraft, sharing food with a person with HIV/AIDS, and mosquito bite, respectively (Table 1).

\section{Determinants of Misconceptions About HIV Transmission Among Ever-Married Women}

According to bivariate analysis, women's educational status, residence, wealth index, husband's educational status, exposure to mass media, ever tested for HIV/AIDS, women's occupation, and religion of respondents had a significant association with all misconception indicators listed (Table 2).

All the variables were entered into multivariate logistic regression analysis. After correcting for possible outliers by logistic regression, women who had never been tested for HIV/AIDS were associated with the misconception that HIV could be transmitted by witchcraft or supernatural means, mosquito bites, and food sharing with an individual with AIDS.

Catholic $(\mathrm{AOR}=2.7 ; 95 \% \mathrm{CI}=1.2-6.15)$ and Muslim religions $(\mathrm{AOR}=2.7 ; 95 \% \mathrm{CI}=1.9-3.85)$ were associated with the misconception that a person could get HIV by witchcraft or supernatural means. Residing in rural areas $(\mathrm{AOR}=1.52 ; 95 \% \quad \mathrm{CI}=1.13-2.0)$, lack of education $(\mathrm{AOR}=2.36 ; 95 \% \mathrm{CI}=1.3-4.23)$, attended primary education $\quad(\mathrm{AOR}=1.8 ; \quad 95 \% \quad \mathrm{CI}=1.03-3.21)$, unemployed $(\mathrm{AOR}=1.17 ; 95 \% \mathrm{CI}=1.04-1.37)$, and no media access $(\mathrm{AOR}=1.34 ; 95 \% \mathrm{CI}=1.14-1.58)$ were associated with the misconception that mosquito bites can transmit HIV.

Poorest wealth index $(\mathrm{AOR}=1.96 ; 95 \% \mathrm{CI}=1.28-2.99)$, residing in rural areas $(\mathrm{AOR}=1.66 ; 95 \% \mathrm{CI}=1.09-2.53)$, mother's with no education $(\mathrm{AOR}=2.78 ; 95 \% \mathrm{CI}=1.03-$ $7.49)$, and the unemployed $(\mathrm{AOR}=1.24 ; 95 \% \mathrm{CI}=1.14$ 1.47) were also associated with the misconception that 
Table I Background Characteristics of the Respondents Among Ever-Married Women in Ethiopia, EDHS 2016. (n=8893)

\begin{tabular}{|c|c|c|c|}
\hline Variables & Category & Frequency & Percentage \\
\hline \multirow[t]{4}{*}{ Age in years } & $15-24$ & 2236 & $22.4 \%$ \\
\hline & $25-34$ & 3716 & $43.9 \%$ \\
\hline & $35-44$ & 2319 & $25.9 \%$ \\
\hline & $45-49$ & 622 & $7.7 \%$ \\
\hline \multirow[t]{2}{*}{ Resident } & Urban & 2433 & $17.4 \%$ \\
\hline & Rural & 6460 & $82.6 \%$ \\
\hline \multirow[t]{4}{*}{ Educational level } & No education & 4886 & $59.2 \%$ \\
\hline & Primary education & 2594 & $29.6 \%$ \\
\hline & Secondary education & 865 & $6.8 \%$ \\
\hline & Higher education & 548 & $4.4 \%$ \\
\hline \multirow[t]{2}{*}{ Ever been tested for HIVIAIDS } & No & 3823 & $48.0 \%$ \\
\hline & Yes & 5070 & $52.0 \%$ \\
\hline \multirow[t]{2}{*}{ Media access } & No & 5050 & $60.1 \%$ \\
\hline & Yes & 3843 & $39.9 \%$ \\
\hline \multirow[t]{5}{*}{ Wealth index } & Poorest & 2324 & $17.7 \%$ \\
\hline & Poorer & $|34|$ & $19.4 \%$ \\
\hline & Middle & 1262 & $20.3 \%$ \\
\hline & Richer & 1260 & $20.3 \%$ \\
\hline & Richest & 2706 & $22.4 \%$ \\
\hline \multirow[t]{5}{*}{ Religion } & Orthodox & 3402 & $42.0 \%$ \\
\hline & Catholic & 54 & $0.8 \%$ \\
\hline & Protestant & 1644 & $22.9 \%$ \\
\hline & Muslim & 3703 & $32.7 \%$ \\
\hline & Other & 90 & $1.7 \%$ \\
\hline \multirow[t]{2}{*}{ Occupation of mother } & Unemployed & 4703 & $50.9 \%$ \\
\hline & Employed & 4190 & $49.1 \%$ \\
\hline \multirow[t]{4}{*}{ Husband education } & No education & 3854 & $45.2 \%$ \\
\hline & Primary education & 2856 & $37.2 \%$ \\
\hline & Secondary education & 1188 & $10.2 \%$ \\
\hline & Higher education & 995 & $7.5 \%$ \\
\hline \multirow[t]{2}{*}{ HIV transmitted by witchcraft } & No & 7955 & $85.5 \%$ \\
\hline & Yes & 938 & $14.5 \%$ \\
\hline \multirow[t]{2}{*}{ HIV transmitted through mosquito bites } & No & 6059 & $66.0 \%$ \\
\hline & Yes & 2834 & $34.0 \%$ \\
\hline \multirow[t]{2}{*}{ HIV transmitted through sharing food with person who has AIDS } & No & 7352 & $81.5 \%$ \\
\hline & Yes & $|54|$ & $18.5 \%$ \\
\hline
\end{tabular}

sharing food with an individual with AIDS could transmit HIV (Table 3).

\section{Discussion}

The main aim of this study is to identify the determinants of misconceptions about the transmission of HIV/AIDS among ever-married women in Ethiopia. Unless these primary factors are correctly recognized and addressed, misconceptions will continue to increase HIV transmission despite knowing the disease. This research shows that some Ethiopian married women endorsed all of the misconception indicators. So, the results of this research showthat $34 \%, 18.5 \%$, and $14.5 \%$ of women believed that mosquito bites, food sharing with an individual who is HIV seropositive, and witchcraft or supernatural means, respectively, were responsible for the acquisition of HIV/ 
Table 2 Bivariate Analysis on the Association with Misconceptions About HIV Transmission Among Ever-Married Women in Ethiopia, EDHS 2016

\begin{tabular}{|c|c|c|c|c|c|c|c|}
\hline \multirow[t]{2}{*}{ Variables } & \multirow[t]{2}{*}{ Category } & \multicolumn{2}{|c|}{ HIV by Witchcraft } & \multicolumn{2}{|c|}{ HIV from Mosquito Bites } & \multicolumn{2}{|c|}{ HIV Through Sharing Food } \\
\hline & & Yes (\%) & $P$-value & Yes (\%) & $P$-value & Yes (\%) & $P$-value \\
\hline Age in years & $\begin{array}{l}15-24 \\
25-34 \\
35-44 \\
45-49\end{array}$ & $\begin{array}{l}270(24.2) \\
384(45.3) \\
231(24.2) \\
53(6.3)\end{array}$ & 0.42 & $\begin{array}{l}720(21.3) \\
1150(43.4) \\
747(27.4) \\
217(8.0)\end{array}$ & 0.41 & $\begin{array}{l}396(21.7) \\
626(40.6) \\
397(29.3) \\
122(8.3)\end{array}$ & 0.103 \\
\hline Resident & $\begin{array}{l}\text { Urban } \\
\text { Rural }\end{array}$ & $\begin{array}{l}|3|(5.4) \\
807(94.6)\end{array}$ & 0.001 & $\begin{array}{l}46 I(10.5) \\
2373(89.5)\end{array}$ & 0.001 & $\begin{array}{l}\mid 40(4.6) \\
|40|(95.4)\end{array}$ & 0.001 \\
\hline Educational & $\begin{array}{l}\text { No education } \\
\text { Primary education } \\
\text { Secondary education } \\
\text { Higher education }\end{array}$ & $\begin{array}{l}665(72.3) \\
228(24.5) \\
34(2.6) \\
I I(0.7)\end{array}$ & 0.001 & $\begin{array}{l}1822(66.5) \\
764(27.2) \\
175(4.6) \\
73(1.7)\end{array}$ & 0.001 & $\begin{array}{l}1170(73.3) \\
315(24.8) \\
41(1.5) \\
15(0.4)\end{array}$ & 0.001 \\
\hline Ever tested for HIV & $\begin{array}{l}\text { No } \\
\text { Yes }\end{array}$ & $\begin{array}{l}586(68.2) \\
352(31.8)\end{array}$ & 0.001 & $\begin{array}{l}\text { I } 449(55.8) \\
\text { I } 385(44.2)\end{array}$ & & $\begin{array}{l}1034(68.5) \\
507(31.5)\end{array}$ & 0.001 \\
\hline Media access & $\begin{array}{l}\text { No } \\
\text { Yes }\end{array}$ & $\begin{array}{l}648(72.0) \\
290(28.0)\end{array}$ & 0.001 & $\begin{array}{l}1775(62.3) \\
1059(37.7)\end{array}$ & 0.085 & $\begin{array}{l}I 160(74.7) \\
381(25.3)\end{array}$ & 0.001 \\
\hline Wealth index & $\begin{array}{l}\text { Poorest } \\
\text { Poorer } \\
\text { Middle } \\
\text { Richer } \\
\text { Richest }\end{array}$ & $\begin{array}{l}359(26.4) \\
176(25.3) \\
141(22.3) \\
111(16.4) \\
151(9.6)\end{array}$ & 0.001 & $\begin{array}{l}957(20.3) \\
461(20.7) \\
458(22.9) \\
397(20.3) \\
561(15.7)\end{array}$ & 0.001 & $\begin{array}{l}704(28.0) \\
27 \mid(24.5) \\
243(23.4) \\
173(16.5) \\
150(7.6)\end{array}$ & 0.001 \\
\hline Religion & $\begin{array}{l}\text { Orthodox } \\
\text { Catholic } \\
\text { Protestant } \\
\text { Muslim } \\
\text { Other }\end{array}$ & $\begin{array}{l}232(24.9) \\
8(1.1) \\
137(17.0) \\
551(55.0) \\
10(2.0)\end{array}$ & 0.001 & $\begin{array}{l}980(39.4) \\
19(1.1) \\
511(22.6) \\
1295(35.3) \\
29(1.7)\end{array}$ & 0.12 & $\begin{array}{l}435(32.9) \\
12(1.1) \\
258(21.5) \\
815(42.3) \\
21(2.3)\end{array}$ & 0.001 \\
\hline Occupation of mother & $\begin{array}{l}\text { Unemployed } \\
\text { Employed }\end{array}$ & $\begin{array}{l}576(58.5) \\
362(4 I .5)\end{array}$ & 0.004 & $\begin{array}{l}1607(55.1) \\
1227(44.9)\end{array}$ & 0.002 & $\begin{array}{l}976(60.0) \\
565(40.0)\end{array}$ & 0.001 \\
\hline Husband education & $\begin{array}{l}\text { No education } \\
\text { Primary education } \\
\text { Secondary education } \\
\text { Higher education }\end{array}$ & $\begin{array}{l}522(53.1) \\
294(37.0) \\
81(7.7) \\
41(2.2)\end{array}$ & 0.001 & $\begin{array}{l}1437(48.6) \\
944(39.0) \\
267(8.3) \\
186(4.0)\end{array}$ & 0.001 & $\begin{array}{l}967(60.1) \\
426(32.7) \\
102(5.8) \\
46(1.5)\end{array}$ & 0.001 \\
\hline
\end{tabular}

AIDS. This finding is also supported by a study done in Thailand among patients with HIV who incorrectly thought that mosquito bites and sharing food with a person who has AIDS could transmit HIV. ${ }^{19}$ Likewise, another study done in China stated that $26.5 \%$ and $70.4 \%$ of women believed that food sharing and mosquito bites, respectively, were responsible for the transmission of HIV/AIDS. ${ }^{8}$ Other studies were done in South Africa stated that $74 \%$ and $11 \%$ of respondents believed that AIDS is caused by mosquito bite and spirits and supernatural forces, respectively. ${ }^{20,21}$ This finding is also in line with other studies done in Ghana, ${ }^{22}$ which showed that $27.50 \%, 20.8 \%$, and $37.9 \%$ of married women thought that HIV could be transmitted through mosquito bites, food sharing with an individual with AIDS, and by witchcraft or supernatural means, respectively, and Punjab, ${ }^{9}$ which showed that $83.1 \%, 79.3 \%$, and $85.3 \%$ of married women believed that HIV could be transmitted through mosquito bites, food sharing with an individual with AIDS, and by witchcraft, respectively. Moreover, a study conducted in Nigeria among mothers of infants, showed that $35.3 \%$ of them believed that mosquito bites could be responsible for 
Table 3 Multivariate Logistic Regression Analysis to Identify Factors Associated with Misconceptions About HIV Transmission Among Ever-Married Women in Ethiopia, EDHS $2016(n=8893)$

\begin{tabular}{|c|c|c|c|c|}
\hline \multirow[t]{2}{*}{ Variables } & & HIV by Witchcraft & HIV from Mosquito Bites & HIV Through Sharing Food \\
\hline & & AOR $(95 \% \mathrm{Cl})$ & AOR $(95 \% \mathrm{Cl})$ & AOR $(95 \% \mathrm{Cl})$ \\
\hline Resident & $\begin{array}{l}\text { Urban } \\
\text { Rural }\end{array}$ & $\begin{array}{l}\text { I } \\
0.50(0.28-0.89)^{*}\end{array}$ & $1.52(1.13-2.0)^{*}$ & $\begin{array}{l}\text { I } \\
1.66(1.09-2.53)^{*}\end{array}$ \\
\hline Mother's Education & $\begin{array}{l}\text { No education } \\
\text { Primary } \\
\text { Secondary } \\
\text { Higher }\end{array}$ & $\begin{array}{l}2.24(0.64-7.80) \\
\text { I.60 }(0.48-5.73) \\
\text { I.32 (0.32-5.40) } \\
\text { I }\end{array}$ & $\begin{array}{l}2.36(1.30-4.23)^{*} \\
1.80(1.03-3.21)^{*} \\
1.50(0.87-2.63) \\
1\end{array}$ & $\begin{array}{l}2.78(1.30-7.49)^{*} \\
2.47(0.92-6.60) \\
1.16(0.40-3.34) \\
1\end{array}$ \\
\hline Ever been tested for HIV & $\begin{array}{l}\text { No } \\
\text { Yes }\end{array}$ & $\begin{array}{l}1.75(1.30-2.34)^{*} \\
\mathrm{I}\end{array}$ & $\begin{array}{l}1.30(1.12-1.52)^{*} \\
1\end{array}$ & $\begin{array}{l}1.80(1.46-2.23)^{*} \\
\mathrm{I}\end{array}$ \\
\hline Media access & $\begin{array}{l}\text { No } \\
\text { Yes }\end{array}$ & $\begin{array}{l}1.06(0.83-1.4) \\
\text { । }\end{array}$ & $\begin{array}{l}1.34(1.14-1.58)^{*} \\
\mathrm{I}\end{array}$ & $\begin{array}{l}\text { I. } 14(0.90-1.40) \\
\text { I }\end{array}$ \\
\hline Wealth index & $\begin{array}{l}\text { Poorest } \\
\text { Poorer } \\
\text { Middle } \\
\text { Richer } \\
\text { Richest }\end{array}$ & $\begin{array}{l}\text { I.40 }(0.80-2.37) \\
1.29(0.80-2.05) \\
\text { I.I2(0.60-I.83) } \\
0.90(0.56-1.56) \\
\text { I }\end{array}$ & $\begin{array}{l}I .25(0.90-|.7|) \\
I .12(0.80-|.5|) \\
I .24(0.92-1.67) \\
I .06(0.80-1.39) \\
I\end{array}$ & $\begin{array}{l}1.96(1.28-2.99)^{*} \\
1.57(1.10-2.24)^{*} \\
1.49(1.05-2.12)^{*} \\
I .17(0.79-1.73) \\
\text { I }\end{array}$ \\
\hline Religion & $\begin{array}{l}\text { Orthodox } \\
\text { Catholic } \\
\text { Protestant } \\
\text { Muslim } \\
\text { Other }\end{array}$ & $\begin{array}{l}\text { I } \\
2.70(1.20-6.15)^{*} \\
1.10(0.80-1.52) \\
2.70(1.90-3.85)^{*} \\
1.35(0.75-2.40)\end{array}$ & $\begin{array}{l}\text { I } \\
1.97(0.70-5.25) \\
0.90(0.78-1.16) \\
1.01(0.80-1.24) \\
0.83(0.45-1.55)\end{array}$ & $\begin{array}{l}\text { I } \\
2.47(1.15-5.28)^{*} \\
1.13(0.80-1.44) \\
1.33(1.06-1.68)^{*} \\
1.01(0.68-1.49)\end{array}$ \\
\hline Occupation of mother & $\begin{array}{l}\text { Unemployed } \\
\text { Employed }\end{array}$ & $\begin{array}{l}1.00(0.80-1.25) \\
1\end{array}$ & $\begin{array}{l}1.17(1.04-1.37)^{*} \\
1\end{array}$ & $\begin{array}{l}1.24(1.14-1.47)^{*} \\
\mathrm{I}\end{array}$ \\
\hline Husband education & $\begin{array}{l}\text { No education } \\
\text { Primary education } \\
\text { Secondary education } \\
\text { Higher education }\end{array}$ & $\begin{array}{l}1.16(0.60-2.25) \\
1.25(0.60-2.40) \\
\text { I.7I (0.9-3.12) } \\
\text { I }\end{array}$ & $\begin{array}{l}\text { I. } 179(0.8-1.64) \\
\text { I.29 (0.94-I.77) } \\
\text { I.20(0.85-I.75) } \\
\text { । }\end{array}$ & $\begin{array}{l}\text { I.99 }(1.08-3.67)^{*} \\
\text { I.48 (0.80-2.7I) } \\
\text { I.66(0.80-3.30) } \\
\text { । }\end{array}$ \\
\hline
\end{tabular}

Notes: *Shows a statistically significant association where $P<0.05$; I: reference category.

the acquisition of AIDS. ${ }^{23}$ The figure variation across different countries may be expounded on the different social and cultural influences between the countries.

Regarding factors associated with misconception indicators of HIV transmission, Muslim religion followers were more likely to possess the misconception about the transmission of HIV than an orthodox follower. This finding is consistent with a study done in Bangladesh. ${ }^{5}$ The consistency might be that Muslim women may have limited access to resources, including opportunities to obtain clinical knowledge about HIV. ${ }^{7}$ Being a catholic religious follower is more likely associated with a misconception of HIV transmission as compared with orthodox, which needs further study for more justification.
A misconception that the sting of a mosquito and food sharing with an individual who lives with AIDS could transmit HIV was more related to women residing in a rural area than urban. This finding also supported other studies done in China, Malawi, and Ghana. ${ }^{7,822}$ This might also be because of the lack of information about the mode of HIV/AIDS transmission; hence most EDHS data were taken from the rural area as compared with urban. In contrary, women residing in a rural area were less likely to endorse the misconception that HIV can be transmitted through witchcraft or supernatural means, which needs further investigation for a possible explanation. In the same vein, women who had no education and attended primary education were more likely to possess the misconception that HIV is transmitted through mosquito bites, and by 
food sharing with an individual who has AIDS than women attended higher education. This finding is also supported by a study conducted in Botswana. ${ }^{6}$ The consistency might be that a higher level of education provides good knowledge and disperses misconceptions about HIV transmission. Women who did not have access to media were more likely to own misconceptions that HIV may be transmitted through the bite of a mosquito than their counterparts. This finding is also supported by a study conducted in Bangladesh. ${ }^{5}$ Similarly, unemployed women were more likely to possess a misconception about HIV transmission through the bite of a mosquito from an infected person and can get HIV by sharing of food with an individual who had HIV/AIDS than people who were employed. This finding is also in line with a study done in Malawi. ${ }^{7}$ Similarly, a woman who had not ever been tested for HIV/AIDS was more likely to possess a misconception for the three indicators than their counterparts. This could be because probably women who have ever been tested for HIV might be counseled by a healthcare provider while they got providerinitiated counseling and testing (PICT).

Additionally, women who were within the poorest, poorer, and middle-income category were more likely of have the misconception that HIV can be transmitted by sharing of food with someone who had HIV/AIDS than the richest. This finding is also supported by studies conducted in Bangladesh, Ghana, and Malawi. 5,7,22 Women's husband's education level is also related to that misconception about the transmission of HIV/AIDS towards the indicator HIV can be transmitted by food sharing and, therefore, no husband education was more likely to lead to misconceptions than those that had higher educated husbands. Similarly, this finding is also in line with research done in Bangladesh among ever-married women. ${ }^{5}$

\section{Strength of Study}

The strength of this study is the large sample sizes used, which make the estimates more reliable and it is possible to infer to general populations.

\section{Limitation of Study}

The researcher was limited to only variables collected by the survey since they have been used secondary data. Another limitation of this study is that the information collected is self-reported, which is liable for reporting errors and biases, and the HIV status of the women is not included as a variable. Additionally, the analysis was limited to ever-married women only. Lastly, since it is a cross-sectional study, we cannot assign causations to any of the associations between the identified factors and the outcomes of interest.

\section{Conclusions}

This research revealed that women residing in a rural area, who did not attend education, did not have access to media, who were catholic and Muslim religion followers, had not ever been tested for HIV, and being unemployed women were strongly associated with a misconception about HIV transmission. Therefore, this study recommends that essential actions should be done to support health education programs through the contribution and cooperation of different governmental and non-governmental organizations. Women should also be given exceptional priority in HIV interventions in all aspects of the social, political, and economic situation. Additionally, interventional programs should be taken into account to eradicate misconceptions about HIV. Finally, further qualitative and comparative research should be done among ever-married women and men by addressing other variables for a possible explanation.

\section{Abbreviations}

AIDS, acquired immune deficiency syndrome; AOR, adjusted odd ratio; $\mathrm{CI}$, confidence interval; EDHS, Ethiopian Demographic Health Survey; EAs, enumeration areas; PHC, population and housing census; HIV, human immune deficiency virus; SPSS, Statistical Package Software for Social Science.

\section{Data Sharing Statement}

We used the USAID-DHS program 2016 Ethiopian Demographic and Health Survey data set. To request the same or different data for another purpose, a new research project request should be submitted to the DHS program here: https://dhsprogram.com/data/AccessInstructions.cfm.

The DHS Program will normally review all data requests within 24-48 hours (during working days) and provide notification if access has been granted, or additional project information is needed before access can be granted. After receiving permission, the researcher can log in and select the specific data in the format they prefer.

\section{Acknowledgments}

We are grateful to the USAID-DHS program for providing access to the 2016 Ethiopian Demographic Health Survey. 


\section{Author Contributions}

All authors made a significant contribution to the work reported, whether that is in the conception, study design, execution, acquisition of data, analysis, and interpretation, or in all these areas; took part in drafting, revising or critically reviewing the article; gave final approval of the version to be published; have agreed on the journal to which the article has been submitted; and agree to be accountable for all aspects of the work.

\section{Funding}

There is no funding to report.

\section{Disclosure}

The authors confirm that this research is their original paper and that there is no conflict of interest in this work.

\section{References}

1. Assefa B. A Review on the socio-economic impact of HIV-AIDS in Ethiopia.Journal of Economics and Sustainable Development. 2018,9(1)

2. Khan MA, Rahman M, Khanam PA, Barkat EK, Kane TT, Ashraf A. Awareness of sexually transmitted disease among women and service providers in rural Bangladesh. BMC Public Health. 1997;8(11):688-696.

3. Sahile Z, Mekuria M, Yared A. Comprehensive HIV/AIDS knowledge and sexual behavior among university students in Ambo, central Ethiopia: implication to improve intervention. J Sex Transm Dis. 2015;2015:1-6. doi:10.1155/2015/890202

4. Central Statistical Agency (CSA) [Ethiopia] and ICF. Ethiopia Addis Ababa E, and Rockville, Maryland, USA, CSA, and ICF. Demographic and Health Survey; 2016.

5. Mondal MN, Hoque N, Chowdhury MR, Hossain MS. Factors associated with misconceptions about HIV transmission among ever-married women in Bangladesh. Jpn J Infect Dis. 2015;68(1):13-19. doi:10.7883/yoken.JJID.2013.323

6. Letamo G. Misconceptions about HIV prevention and transmission in Botswana. Afr J AIDS Res. 2007;6(2):193-198. doi:10.2989/ 16085900709490414

7. Sano Y, Antabe R, Atuoye KN, et al. Persistent misconceptions about HIV transmission among males and females in Malawi. BMC Int Health Hum Rights. 2016;16(1):16. doi:10.1186/s12914-016-0089-8

8. Qian H-Z, Wang N, Dong S, et al. Association of misconceptions about HIV transmission and discriminatory attitudes in rural China. AIDS Care. 2007;19(10):1283-1287. doi:10.1080/09540120701402814

9. Rashid M. Socio-economic factors of misconception about HIV/AIDS among ever-married women in Punjab: a comparison of non-spatial and spatial hierarchical Bayesian Poisson model. Kuwait J Sci. 2019;46(4).

HIV/AIDS - Research and Palliative Care

\section{Publish your work in this journal}

HIV/AIDS - Research and Palliative Care is an international, peerreviewed open-access journal focusing on advances in research in HIV, its clinical progression and management options including antiviral treatment, palliative care and public healthcare policies to
10. Ahmed M, Seid A. Factors associated with premarital HIV testing among married women in Ethiopia. PLoS One. 2020;15(8):e0235830. doi:10.1371/journal.pone. 0235830

11. Machacha L, editor. Power sharing, decision making, gender and HIV/AIDS: an assessment of targets, progress made and power relations. Ministry of Labour and Home Affairs' Report of the First National Conference on Gender and HIV/AIDS; Republic of Botswana. 2001.

12. Maziz MNH, Fazlul M, Deepthi S, et al. A study of comparison on knowledge and misconceptions about Hiv/Aids among students in a private university In Malaysia. Malaysian J Public Health Med. 2019;19(1):134-142. doi:10.37268/mjphm/vol.19/no.1/art.45

13. Nazmul M, Farzana Y, Deepthi S, Fazlul M, Najnin A, Srikumar C. General knowledge and misconceptions about HIV/AIDS among the university students in Malaysia. Indian J Public Health Res Dev. 2018;9(10):435-440. doi:10.5958/0976-5506.2018.01383.9

14. Gerbi GB, Habtemariam T, Tameru B, Nganwa D, Robnett V. A quantitative risk assessment of multiple factors influencing HIV/AIDS transmission through unprotected sex among HIV-seropositive men. AIDS Care. 2012;24(3):331-339. doi:10.1080/09540121.2011.608418

15. Mooss A, Brock-Getz P, Ladner R, Fiaño T. The relationship between health literacy, knowledge of health status, and beliefs about HIV/ AIDS transmission among Ryan White clients in Miami. Health Educ J. 2013;72(3):292-299. doi:10.1177/0017896912442952

16. Letamo G. Misconceptions about HIV transmission among adolescents: levels, trends and correlates from the Botswana AIDS impact surveys, 2001-2013: a short report. AIDS Care. 2019;31(1):48-52. doi:10.1080/09540121.2018.1488030

17. Tenkorang EY, Gyimah S, Maticka-Tyndale E, Adjei J. Superstition, Witcheraft and AIDS prevention in Sub-Saharan Africa: the case of Ghana. Cult Health Sex. 2011;13(9):1001-1014. doi:10.1080/ 13691058.2011.592218

18. OFFICE FHAPAC. HIV/AIDS Strategic Plan 2015-2020 in an Investment Case Approach. Addis Ababa; 2014.

19. Jittimanee SX, Nateniyom S, Kittikraisak W, et al. Social stigma and knowledge of tuberculosis and HIV among patients with both diseases in Thailand. PLoS One. 2009;4(7):e6360. doi:10.1371/journal. pone. 0006360

20. Rauf W, Hitchcock S, Rauf A, Becker PJ. Knowledge of and misconceptions about the spread and prevention of HIV infection among older urban women attending the Tshwane District Hospital, South Africa. $S$ Afr Fam Pract. 2010;52(2):142-148. doi:10.1080/ 20786204.2010.10873957

21. Kalichman SC, Simbayi L. Traditional beliefs about the cause of AIDS and AIDS-related stigma in South Africa. AIDS Care. 2004;16(5):572-580. doi:10.1080/09540120410001716360

22. Tenkorang EY. Myths and misconceptions about HIV transmission in Ghana: what are the drivers? Cult Health Sex. 2013;15(3):296-310. doi:10.1080/13691058.2012.752107

23. Kayode C, Adeyemo A, Omotade O. Beliefs and perceptions about HIV infection and AIDS among mothers of infants in Ibadan, Nigeria. West Afr J Med. 2002;21(1):43-47. control viral spread. The manuscript management system is completely online and includes a very quick and fair peer-review system, which is all easy to use. Visit http://www.dovepress.com/testimonials.php to read real quotes from published authors.

\section{Dovepress}

